\title{
PENGEMBANGAN BETON RINGAN DARI LUMPUR SIDOARJO SEBAGAI BETON STRUKTURAL SESUAI SNI 2847:2013
}

\section{Lightweight Concrete Development From Sidoarjo Mud As a Struktural Concrete in Accordance of SNI 2847:2013}

\author{
Lasino \\ Puslitbang Perumahan dan Permukiman, \\ Jl. Panyawungan, Cileunyi Wetan, Bandung \\ Email: Isn_pu@yahoo.com
}

\begin{abstract}
Abstrak
Lumpur Sidoarjo (LUSI), merupakan bahan mineral yang dikeluarkan dari dalam bumi akibat kegagalan teknis dalam pengeboran (eksplorasi) migas di Porong Sidoarjo. Material tersebut dalam istilah geologi dapat dikategorikan sebagai produk erupsi mud volcano yang bisa terjadi di suatu kegiatan pengeboran khususnya diwilayah yang mempunyai tatanan geologi yang kompleks. Bahan ini berbentuk butiran halus, berwarna abuabu kehitaman dan sangat plastis. Dari hasil penelitian diperoleh bahwa unsur kimia yang terkandung didominasi oleh silika (> $50 \%$ ), alumina (> $25 \%$ ), besi (> $8 \%$ ) dan beberapa unsur lain seperti kalsium dan magnesium dengan jumlah yang relatif kecil.Dalam upaya peningkatan nilai guna dan pemanfaatannya, akan dikembangkan beton ringan yang memenuhi syarat untuk beton struktural. Proses pembentukan beton ringan dilakukan dengan membuat agregat ringan melalui pembakaran setelah bahan baku dikeringkan, dicrusher dan diayak sampai menjadi ukuran nominal $10 \mathrm{~mm}$, dan selanjutnya dibakar menggunakan tungku putar pada suhu sintering $\left(900^{\circ} \mathrm{C}-1.000^{\circ} \mathrm{C}\right)$. Hasil pengujian menunjukkan bahwa beton ringan dari lusi cukup baik, kuat, ringan dan stabil dengan kuat tekan dapat mencapai mutu f'c $20 \mathrm{MPa}$ (K. 250) dengan densitas 1,3-1,4 kg/ltr dimana nilai tersebut telah memenuhi syarat SNI 2847 tentang Persyaratan Beton Struktural untuk Bangunan Gedung. Karena volume lumpur ini sangat banyak /besar dan termasuk bahan yang sangat mengganggu lingkungan, maka dengan pemanfaatannya sebagai beton ringan diharapkan dapat mengurangi dampak yang ditimbulkan dan beton yang dihasilkan termasuk bahan yang ramah lingkungan.
\end{abstract}

Kata kunci : Beton ringan, , agregat ringan, lumpur Sidoarjo, mineral alam, ramah lingkungan.

\begin{abstract}
Mud Sidoarjo (LUSI), is a mineral material released from the earth due to technical failure in oil and gas exploration (exploration) in Porong Sidoarjo. These materials in geological terms can be categorized as mud volcano eruption products that can occur in a drilling activity, especially in areas that have a complex geological order. This material is in the form of fine granules, blackish gray and very plastic. From the results of the study it was found that the chemical elements contained were dominated by silica (>50\%), alumina (>25\%), iron (> 8\%) and several other elements such as calcium and magnesium with relatively small amounts. In an effort to increase the value of use and utilization, lightweight concrete will be developed that meets the requirements for structural concrete. The process of forming lightweight concrete is done by making lightweight aggregates through combustion after the raw material is dried, crushed and sieved to a nominal size of $10 \mathrm{~mm}$, and then burned using a rotary furnace at sintering temperatures (900 OC - 1,000oC). The test results show that lightweight concrete from warp is quite good, strong, light and stable with compressive strength can reach f'c quality of $20 \mathrm{MPa}(\mathrm{K}$. 250) with a density of $1.3-1.4 \mathrm{~kg} / \mathrm{Itr}$ where the value meets the requirements SNI 2847 concerning Structural Concrete Requirements for Buildings. Because the volume of sludge is very large and includes materials that are very disturbing to the environment, then its use as lightweight concrete is expected to reduce the impact and the resulting concrete, including materials that are environmentally friendly.
\end{abstract}

Keywords : lightweight concrete, lightweight aggregate, Sidoarjo mud, natural minerals, environmentally friendly.

\section{PENDAHULUAN}

Semburan lumpur Sidoarjo yang telah berlangsung sejak tahun 2006 masih menunjukkan keaktifannya, lumpur masih terus menyembur dan mengeluarkan asap dari pusat semburan yang berlokasi di Desa Siring, Porong, Sidoarjo. Hal tersebut telah menimbulkan kerugian besar baik secara langsung maupun tidak langsung dengan rusaknya bangunan dan fasilitas umum, lingkungan, tempat usaha serta terhentinya kegiatan ekonomi di wilayah tersebut.Peristiwa semburan lumpur panas ini termasuk salah satu bencana yang dipicu oleh kegiatan industri pertambanganyang mana sampai saat 
ini belum dapat ditanggulangi sehingga menambah penderitaan masyarakat yang terkena dampak di daerah tersebut.Material lumpur tersebut berbentuk butiran halus, berwarna abu-abu kehitaman, sangat plastis, dan memiliki nilai susut kering yang tinggi. Dari hasil penelitian terdahulu diperoleh data bahwa unsurkimia yang terkandung didominasi oleh silika (> $50 \%$ ), alumina (26\%), dan beberapa unsur lain seperti besi, calsium dan magnesium dengan jumlah yang relative kecil.

Berdasarkan sifat-sifat dasar yang dimiliki serta hasil penelitian terdahulu yang telah dilakukan ternyata lumpur tersebut setelah ditambah dengan abu batu bara dapat dikembangkan menjadi bata merah, genteng keramik, dan agregat ringan melalui proses pembakaran dengan hasil yang cukup baik, keras, stabil dan memiliki bobot relatif ringan dibanding dengan bahan keramik pada umumnya. Pengembangan lainnya yang dapat dilakukan adalah pembuatan beton polimer dari lumpur tersebut melalui proses pembakaran menjadi bahan pozolan terlebih dahulu dan dihaluskan. Oleh karenanya seiring dengan upaya penghematan energi dan pengurangan emisi gas, maka dalam rangka pemecahan masalah dengan tanpa merusak lingkungan, akan dilakukan penelitian pengembangan beton polimer dengan tambahan bahan aditif serta pengembangan bata merah yang dapat digunakan untuk bangunan perumahan.

Penelitian ini dimaksudkan untuk mengetahui sifat teknis bahan baku khususnya sebagai bahan dasar dalam pembuatan agregat ringan dan beton ringan. Dengan demikian dalam pengembangannya dapat diberikan suatu perlakuan yang tepat untuk menghasilkan produk yang baik dan memenuhi syarat ditinjau dari aspek proporsi bahan tambahan, optimalisasi suhu bakar dan waktu pembakaran serta sifat-sifat teknis dari beton polimer.Lingkup penelitian meliputi analisis bahan baku (sifat kimia, fisik dan mekanik), pembakaran lusi daan pembuatan beton ringan.Melalui serangkaian penelitian tersebut, diharapkan diperoleh suatu komponen yang memenuhi persyaratan teknis dengan proporsi campuran dan suhu bakar yang optimum serta beton ringan dengan bahan baku lumpur Sidoarjo.

Dengan demikian adanya semburan lumpur yang sangat melimpah dan telah menutupi sebagian besar area sekitar wilayah di Sidoarjo Jawa Timur ini nantinya dapat dikelola dan dimanfaatkan secara baik sebagai material konstruksi dan mengurangi dampak negative. Disamping hal tersebut dengan semakin meningkatnya kebutuhan material dalam kegiatan industri konstruksi perlu disediakandengan jumlah yang cukup baik secara kualitas maupun kuantitas. Hal lainnya adalah perlunya diciptakan kesempatan kerja dan peluang usaha bagi masyarakat setempat yang terkena dampak sehingga dapatmeningkatkan ekonomi melalui pembentukan unit usaha bahan bangunan. Permasalahannya adalah produk apa yang bisa dikembangkan serta teknologi yang sesuai untuk masyarakat setempat, perlu dikembangkan lebih jauh yang berorientasi pada pemanfaatan bahan lokal (lumpur), proses yang sederhana, teknologi tepat guna dan metoda yang sesuai dengan tingkat kemampuan masyarakat.

Tujuan dari penelitin ini adalah untuk mengembangkan beton ringandari Lumpur Sidoarjo dengan proses pembakaran sehingga diperoleh agregat ringan yang kuat, ringan dan stabil sehingga memenuhi syarat sebagai agregat untuk beton ringan struktural sesuai SNI. 2461:2014, persyaratan agregat ringan untuk beton strukturaldan selanjutnya digunakan untuk pembuatan beton ringan yang kuat, awet dan stabil sehingga dapat memenuhi persyaratan SNI 2847:2013 tentang Persyaratan Beton Struktural untuk Bangunan Gedung.

\section{TINJAUAN PUSTAKA}

Lumpur Sidoarjo dengan sifat fisis yang sangat halus, berwarna abu-abu kehitaman, sangat plastis, dan memiliki nilai susut kering yang tinggi dan memiliki unsur kimia silika (> $50 \%$ ), alumina (26\%), dan beberapa unsur lain seperti besi, kalsium dan magnesium dengan jumlah yang relatif kecil. Dengan unsur silika dan alumina yang terkandung tersebut akan dikembangkan menjadi agregat ringan melalui proses pembakaran sehingga akan diperoleh suatu butiran yang ringan, kuat dan stabil serta dapat digunakan untuk agregat dalam pembuatan beton ringan struktural $^{[1]}$. Indikasi tersebut juga dapat diperkirakan berdasarkan proses terjadinya pembekahan yang pada prinsipnya memerlukan dua kondisi, yaitu bahan baku harus mempunyai komposisi kimia yang seimbang antara flux ( $\mathrm{CaO}, \mathrm{MgO}, \mathrm{FeO}, \mathrm{Fe}_{2} \mathrm{O}$, $\left.\mathrm{K}, \mathrm{Na}_{2} \mathrm{O}\right)$, silika $\left(\mathrm{SiO}_{2}\right)$, dan alumina $\left(\mathrm{Al}_{2} \mathrm{O}_{3}\right)$ untuk menghasilkan leburan yang viskous cukup untuk menahan gas yang timbul pada temperatur tinggi, serta mengandung zat-zat yang dapat terurai atau bereaksi dengan konstituen lain untuk menghasilkan gas pada temperatur dimana terjadi leburan ${ }^{[2]}$. 
Persyaratan bahan baku tanah liat untuk bahan keramik dan agregat buatan berdasarkan unsur kimianya ${ }^{[3]}$ adalah:

$\begin{array}{ll}\mathrm{SiO}_{2} & : 50-70 \% \\ \mathrm{Al}_{2} \mathrm{O}_{3} & : 10-35 \% \\ \mathrm{Fe}_{2} \mathrm{O}_{3} & : 2-8 \% \\ \mathrm{TiO}_{2} & : 0,1-2 \% \\ \mathrm{CaO} & : 0,5-15 \% \\ \mathrm{MgO} & : 0,2-5 \% \\ \mathrm{SO}_{3} & : 0-0,5 \% \\ \mathrm{HP} & : 3-12 \%\end{array}$

Langkah pertama yang dilakukan untuk pembuatan beton ringan adalah pembuatan agregat ringan dari lusidengan tahapan pengeringan dan pemecahan dari bahan lumpur kemudian disaring untuk mendapatkan butiran dengan ukuran tertentu, selanjutnya dibakar pada suhu sentering antara $900^{\circ} \mathrm{C}-$ $1000^{\circ} \mathrm{C}$ dengan menggunakan tungku putar(rotary kiln) ${ }^{[3]}$. Beberapa persyratan yang harus dipenuhi dari agregat ringan sruktural ini adalah berat jenis maksimum 1,8 , penyerapan air maksimum $20 \%$, bobot isi gembur maksimum $0,9 \mathrm{~kg} / \mathrm{L}$ dan kekerasan dengan nilai keremukan $10 \%$ adalah 9,0 - 14 ton, sedangkan mutu beton yang dapat dicapai minimum adalah f'c $17 \mathrm{MPa}$ (benda uji silinder) atau K. 200 (benda uji kubus) ${ }^{[1]}$. Tujuan penelitian ini adalah untuk menghasilkan beton ringan dengan menggunakan agregat ringan dari lusi yang memenuhi syarat mutu beton ringan struktural. Dengan demikian dalam pengembangannya dapat diberikan suatu perlakuan yang tepat untuk menghasilkan produk yang baik, ekonomis dan praktis. Untuk mencapai sasaran penelitian, maka perlu disusun rencana strategi yang tertuang dalam lingkup dan metoda penelitian yang meliputi analisis bahan baku, uji coba pembakaran, hasil uji agregat dan pembuatan beton ringandengan beberapa proporsi campuran ${ }^{[4]}$.

Berdasarkan SNI 2461:2014, persyaratan agregat ringan untuk beton struktural meliputi ${ }^{[1]}$ : gradasi; Persyaratan sifat fisis; dan Persyaratan kuat tekan dan kuat tarik belah beton yang dihasilkan, yang diuraikan dalam Tabel 1, Tabel 2 dan Tabel 3 berikut.

Tabel 1 Persyaratan susunan besar butir agregat ringan untuk beton ringan struktural.

\begin{tabular}{|c|c|c|c|c|c|c|c|c|c|}
\hline \multirow{2}{*}{$\begin{array}{l}\text { Ukuran ayakan } \\
(\mathrm{mm})\end{array}$} & \multicolumn{9}{|c|}{ Persentasi yang lolos ayakan (\% berat) } \\
\hline & 25,0 & 19,0 & 12,5 & 9,5 & 4,75 & 2,36 & 1,18 & 0,60 & 0,30 \\
\hline \multicolumn{10}{|l|}{ Agregat halus: } \\
\hline $4,75-0,0 \mathrm{~mm}$ & - & - & - & 100 & $85-100$ & - & $40-80$ & $10-35$ & $5-25$ \\
\hline \multicolumn{10}{|l|}{ Agregat kasar: } \\
\hline $25,0-4,75 \mathrm{~mm}$ & $95-100$ & - & $25-60$ & - & $0-10$ & - & - & - & - \\
\hline $19,0-4,75 \mathrm{~mm}$ & 100 & $90-100$ & - & $10-50$ & $0-15$ & - & - & - & - \\
\hline $12,5-4,75 \mathrm{~mm}$ & - & 100 & $90-100$ & $40-80$ & $0-20$ & $0-10$ & - & - & - \\
\hline $9,5-2,36 \mathrm{~mm}$ & - & - & 100 & $80-100$ & $5-40$ & $0-20$ & $0-10$ & - & - \\
\hline \multicolumn{10}{|l|}{ Agregat gabungan } \\
\hline $12,5-8,0 \mathrm{~mm}$ & - & 100 & $95-100$ & - & $50-80$ & - & - & $5-20$ & $2-15$ \\
\hline $9,5-8 \mathrm{~mm}$ & - & - & 100 & $90-100$ & $65-90$ & $35-65$ & - & $10-25$ & $5-15$ \\
\hline
\end{tabular}

Tabel 2 Persyaratan sifat fisis agregat ringan untuk beton ringan struktural.

\begin{tabular}{|c|c|c|}
\hline No & Sifat fisis & Persyaratan \\
\hline 1 & Berat jenis & $1,0-1,8$ \\
\hline 2 & Penyerapan air maksimum, setelah direndam 24 jam, ...... \% & 20 \\
\hline 3 & Berat isi maksimum, gembur kering ,................... kg $/ \mathrm{m}^{3}$ & \\
\hline & - Agregat halus & 1.120 \\
\hline & - Agregat kasar & 880 \\
\hline & - Campuran agregat halus dan kasar & 1.040 \\
\hline 4 & 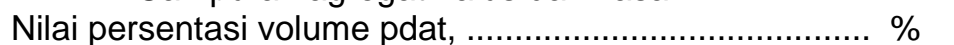 & 60 \\
\hline 5 & 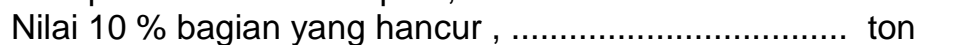 & $9-14$ \\
\hline 6 & Kadar bagian yang terapung setelah direndam dalam air 10 & \\
\hline & 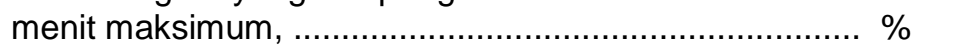 & 5 \\
\hline 7 & 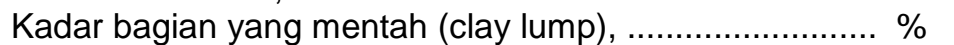 & $<1$ \\
\hline 8 & Nilai keawetan, jika dalam larutan magnesium sulfat selama & \\
\hline & 16 -18 jam, bagian yang larut maksimum, ..................... \% & 12 \\
\hline
\end{tabular}


Tabel 3 Persyaratan kuat tekan dan kuat tarik belah untuk beton ringan struktural.

\begin{tabular}{ccc}
\hline $\begin{array}{c}\text { Berat isi kering udara 28 hari, } \\
\text { maksimum }\left(\mathrm{kg} / \mathrm{m}^{3}\right)\end{array}$ & $\begin{array}{c}\text { Kuat tarik belah rata-rata } \\
(\mathrm{Mpa})\end{array}$ & $\begin{array}{c}\text { Kuat tekan rata-rata, 28 hari } \\
(\mathrm{Mpa})\end{array}$ \\
\hline 1.760 & Semua agregat ringan & 28 \\
1.680 & 2,2 & 21 \\
1.600 & 2,1 & 17 \\
& 2,0 & 28 \\
1.840 & Agregat ringan dan pasir & 21 \\
1.760 & 2,3 & 17 \\
1.680 & 2,1 & 2,0 \\
\hline
\end{tabular}

\section{METODE PENELITIAN}

\section{Bahan dan alat penelitian}

\section{Tanah}

Tanah sebagai bahan baku berupa lumpur yang diambil dari lokasi semburan lumpur Sidoarjo pada kolam penimbunan/pengendapan di 2 (dua) lokasi, yaitu kolam 1 dan kolam 2, dengan masingmasing dilakukan di 3 (tiga) titik / lokasi, sehingga seluruhnya terdapat 6 (enam) titik lokasi yang selanjutnya di campur menjadi satu dan di proses dengan cara pembakaran menjadi produk agregat ringan.

\section{Alat pembakaran}

Alat yang digunakan untuk pembakaran agregat menggunakan tungku putar (rotary kiln) yang ada di kantor Loka Teknologi Perumahan dan Permukiman Cilacap.

\section{Alat uji agregat}

Pengujian agregat (kekerasan, densitas, gradasi, dan lainnya) menggunakan alat uji di laboratorium di kantor Loka Teknologi Permukiman Cilacap.

\section{Alat uji beton}

Alat yang digunakan untuk uji coba pembuatan beton (concrete trial mixed) dan pembuatan komponen risha adalah peralatan laboratorium bahan dan struktur bangunan Pusat Litbang Perumahan dan Permukiman Bandung.

\section{Metode penelitian}

Metode penelitian yang digunakan adalah eksperimental laboratorium dengan membuat benda uji berupa agregat ringan dan beton ringan. Suhu bakar untuk mendapatkan suhu optimum dalam pembuatan agregat ringan divariasikan antara $800^{\circ} \mathrm{C}$ sampai dengan $1.100^{\circ} \mathrm{C}$ seperti yang terlihat pada Tabel 1 . Variasi suhu bakar tersebut untuk mendapatkan hasil yang optimal. Dengan demikian ada empat hal yang ingin dicapai dari penelitian ini, yaitu karakteristik dari lumpur Sidoarjo, optimalisasi suhu bakar,mutu agregat ringan dankarakteristik beton ringan yang dihasilkan. Rancangan uji coba pembakaran agregat dengan alat tungku pijar (muffle furnace) dengan berbagai variasi suhu bakar seperti terlihat pada Tabel 4.

Tabel 4. Rancangan uji coba suhu bakar agregat ringan

\begin{tabular}{lcccc}
\hline \multirow{2}{*}{ No } & \multicolumn{2}{c}{ Tahap-1 } & \multicolumn{2}{c}{ Tahap-2 } \\
\cline { 2 - 5 } & Suhu bakar & Waktu & Suhu bakar & Waktu \\
\hline 1 & $800{ }^{\circ} \mathrm{C}$ & 5 menit & $800{ }^{\circ} \mathrm{C}$ & 10 menit \\
2 & $900{ }^{\circ} \mathrm{C}$ & 5 menit & $900{ }^{\circ} \mathrm{C}$ & 10 menit \\
3 & $1.000^{\circ} \mathrm{C}$ & 5 menit & $1.000^{\circ} \mathrm{C}$ & 10 menit \\
4 & $1.100{ }^{\circ} \mathrm{C}$ & 5 menit & $1.100{ }^{\circ} \mathrm{C}$ & 10 menit \\
\hline
\end{tabular}

Uji coba pembakaran agregat dengan berbagai variasi suhu dan waktu bakar sebagaimana diuraikan dalam table 4 diatas untuk mendapatkan hasil bakar yang optimal, agregat cukup matang, ringan dan memenuhi syarat untuk beton ringan structural. Pengamatan tingkat kesempurnaan pembakaran berdasarkan suhu dan waktu bakar diperiksa berdasarkan kondisi fisik dan kekerasan agregat dengan melakukan pengujian yang mencakup kondisi fisik (tingkat kerataan warna), bentuk butiran (meleleh, gosong dan menggumpal). Setelah diperoleh suhu dan waktu bakar yang optimal, selanjutnya dilakukan pembakaran skala penuh dengan menggunakan tungku putar (rotary kiln) dengan menyesuaikan kecepatan putar dan kelandaian posisi tungku sehingga diperoleh suhu dan waktu bakar yang 
sesuai $^{[5]}$. Hasil pembakaran dengan tungku putar berupa butiran agregat ringan dengan berbagai ukuran yang termasuk dalam kategori agregat kasar (kerikil), agregat halus (pasir), filler dan debu dan dilakukan pengujian yang meliputi kadar air, penyerapan air, berat jenis, bobot isi dan kekerasan.

\section{HASIL DAN PEMBAHASAN}

\section{Hasil pengujian sifat fisis lumpur Sidoarjo}

Sebagai dasar dalam pengembangan lumpur Sidoarjo untuk agregat ringan, maka dilakukan pengujian bahan baku yang meliputi sifat fisis dan kimia terlebih dahulu sehingga dapat dilakukan hipotesis baik dalam proses maupun perkiraan hasil yang akan diperoleh. Hasil pengujian sifat fisis lumpur Sidoarjo yang meliputi indeks plastis, klasifikasi tanah, densitas, gradasi atau besar butir, nilai DSE, susut kering, susut baakar dan kuat lentur disajikan dalam Tabel

5.

Tabel 5 Hasil Pengujian Sifat Fisis lumpur Sidoarjo

\begin{tabular}{|c|c|c|c|c|}
\hline No & Uraian uji & Hasil uji & $\begin{array}{c}\text { Persyaratan } \\
\text { bahan keramik }\end{array}$ & Keterangan \\
\hline 1 & Indek plastis (IP), ,..... \% & 37,40 & $<30,00$ & sangat plastis \\
\hline 2 & Klasifikasi & $\mathrm{CH}$ & - & lanau plastisitas tinggi \\
\hline \multirow[t]{2}{*}{3} & Berat isi basah, $\ldots . . . \mathrm{g} / \mathrm{cm}^{3}$ & 1,79 & - & - \\
\hline & Berat isi kering,,$\ldots \mathrm{g} / \mathrm{cm}^{3}$ & 1,12 & 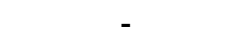 & - \\
\hline \multirow[t]{5}{*}{4} & Besar butir, & & - & - \\
\hline & $>2 \mathrm{~mm}, \ldots$ & 0,00 & - & - \\
\hline & $>0,02 \mathrm{~mm}$, & 22,00 & - & - \\
\hline & $0,02-0,002$ mm, ......... \% & 36,00 & - & - \\
\hline & $<0,002 \mathrm{~mm}, \ldots \ldots \ldots \ldots . . \%$ & 52,00 & - & - \\
\hline 5 & Nilai DSe, & 1,09 & - & peka terhadap pengeringan \\
\hline 6 & Susut kering, ............. \% & 7,10 & - & peka terhadap pengeringan \\
\hline 7 & Susut bakar, ............ $\%$ & 0,72 & - & - \\
\hline 8 & Kuat lentur kering, $\mathrm{kg} / \mathrm{cm}^{2}$ & 11,29 & $>10,00$ & cukup baik \\
\hline
\end{tabular}

Keterangan :Hasil pengujian di Balai Besar Keramik Bandung, 2016.

leburan yang viskous cukup untuk menahan gas yang timbul pada temperatur tinggi, serta mengandung zat-zat yang dapat terurai atau bereaksi dengan konstituen lain untuk menghasilkan gas pada temperatur dimana terjadi leburan ${ }^{[7]}$. plastis dengan indek plastis $37,40 \%$, serta nilai drying shrinkage efisiensi (DSe) dan susut kering yang besar, tetapi memiliki kekuatan lentur kering yang tingg ${ }^{[6]}$. Hasil tersebut mengindikasikan bahwa dalam proses pengeringan akan terjadi penyusutan yang tinggi, tetapi pada saat pembakaran akan terjadi pengembangan akibat adanya

\section{Hasil analisis kimia}

Hasil analisis kimiadari lumpur Sidoarjodisajikan dalam Tabel 6 berikut.

Tabel 6 Hasil pengujian analisis kimia lumpur Sidoarjo

\begin{tabular}{rlrrrrrc}
\hline & Uraian & \multicolumn{5}{c}{ Hasil uji } & Syarat untuk \\
\cline { 3 - 6 } & uji/unsur & Contoh 1 & Contoh 2 & Contoh 3 & Contoh 4 & Rata-rata & bahan keramik \\
\hline 1 & SiO2, (\%) & 52,79 & 48,60 & 52,28 & 54,00 & 51,92 & $50-70$ \\
2 & Al2O3, (\%) & 26,35 & 28,94 & 23,24 & 21,74 & 25,07 & $10-35$ \\
3 & Fe2O3, (\%) & 8,51 & 8,37 & 8,26 & 8,34 & 8,37 & $2-8$ \\
4 & CaO, (\%) & 1,97 & 3,92 & 4,76 & 6,08 & 4,18 & $0,5-15$ \\
5 & MgO, (\%) & 2,53 & 2,21 & 2,42 & 3,49 & 2,66 & $0,2-5$ \\
6 & K2O, (\%) & 2,86 & 2,96 & 2,90 & 1,08 & 2,45 & - \\
7 & Na2O3, (\%) & 2,08 & 1,71 & 2,17 & 2,11 & 2,02 & - \\
8 & SO3, (\%) & 0,98 & 0,97 & 0,92 & 0,96 & 0,96 & $0-0,5$ \\
9 & HP, (\%) & 1,92 & 1,06 & 1,76 & 1,67 & 1,60 & $3-12$ \\
\hline
\end{tabular}

Keterangan :Hasil pengujian di laboratoium Balai Besar Keramik Bandung, 2016. 
Sedangkan dari tabel 3 terlihat bahwa unsur kimia yang terkandung dalam lumpur didominasi oleh unsur silika, alumina dan besi dengan jumlah unsur $\mathrm{SiO}_{2}+\mathrm{Al}_{2} \mathrm{O}_{3}+\mathrm{Fe}_{2} \mathrm{O}_{3}$ sebesar 85,36\%, dengan kandungan unsur tersebut, maka bahan ini sangat baik untuk digunakan sebagai bahan keramik seperti agregat buatan ${ }^{[7]}$. Hal penting lainnya adalah bagian hilang pijar sangat kecil yang mengindikasikan bahwa bahan organik sangat rendah termasuk unsur sulfur yang dapat mengganggu pengikatan semen dan keawetan beton atau mortar saat agregat digunakan dalam adukan ${ }^{[8]}$.

\section{Hasil uji coba pembakaran agregat ringan}

Uji coba pembakaran agregat ringan dari lusi dimaksudkan untuk memperoleh suhu maksimum dan waktu optimum dalam proses pembakaran, sehingga diperoleh hasil agregat yang baik dengan sifat fisisyang memenuhi syarat untuk agregat beton ringan struktura ${ }^{[9]}$. Proses uji coba pembakaran dengan berbagai suhu dan hasil yang diperoleh disajikan pada Gambar 1 berikut:

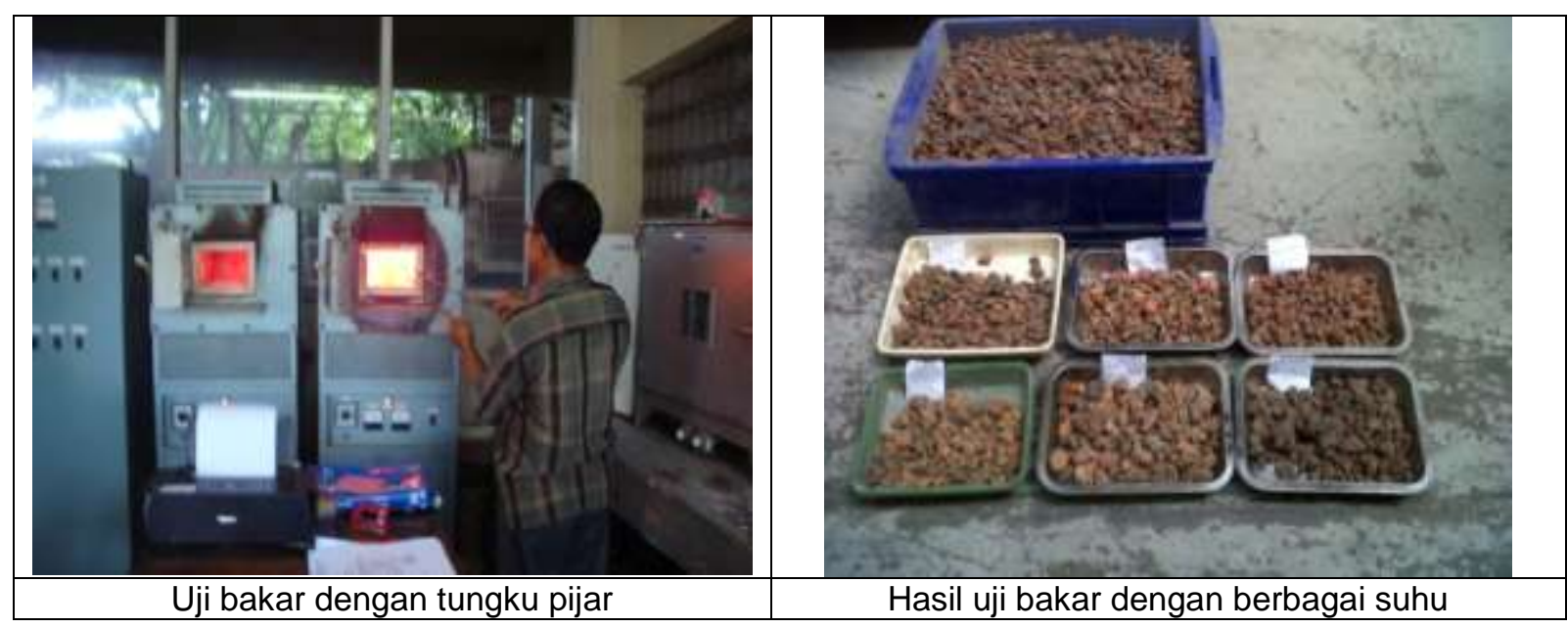

Gambar 1 Uji coba pembakaran agregat ringan

Hasil uji bakar dengan suhu bervariasi antara $800{ }^{\circ} \mathrm{C}$ sampai dengan $1.100{ }^{\circ} \mathrm{C}$, diperoleh data:

Waktu pembakaran selama 5 menit:

a. Pada suhu $800{ }^{\circ} \mathrm{C} \mathrm{s} / \mathrm{d} 1.000{ }^{\circ} \mathrm{C}$, sampel belum cukup matang dan warna belum merata antara bagian luar dan bagian tengah (inti) agregat, ini menandakan waktu pembakaran belum cukup;

b. Pada suhu $1.100{ }^{\circ} \mathrm{C}$,sampel cukup matang disertai bercak gosong pada bagian luar, tetapi belum merata sampai pada inti agregat, hal ini berarti waktu pembakaran masih perlu ditambah;
Waktu pembakaran selama 10 menit:

a. Pada suhu $800{ }^{\circ} \mathrm{C}$, sampel belum cukup matang dan warna belum merata;

b. Pada suhu $900 \mathrm{~s} / \mathrm{d} 1.000{ }^{\circ} \mathrm{C}$ contoh cukup matang, keras dan warna merata ;

c. Pada suhu $1.100^{\circ} \mathrm{C}$,sampel terlalu matang, warna hitam/gosong dan material menjadi leleh dan menggumpal/lengket antara butian agregat satu dengan lainnya;

Berdasarkan hasil uji coba pembakaran tersebut selanjutnya digunakan sebagai acuan dalam produksi agregat ringan dalam skala penuh dengan menggunakan tungku putar (rotarry kiln) yang dapat dilihat pada Gambar 2. 


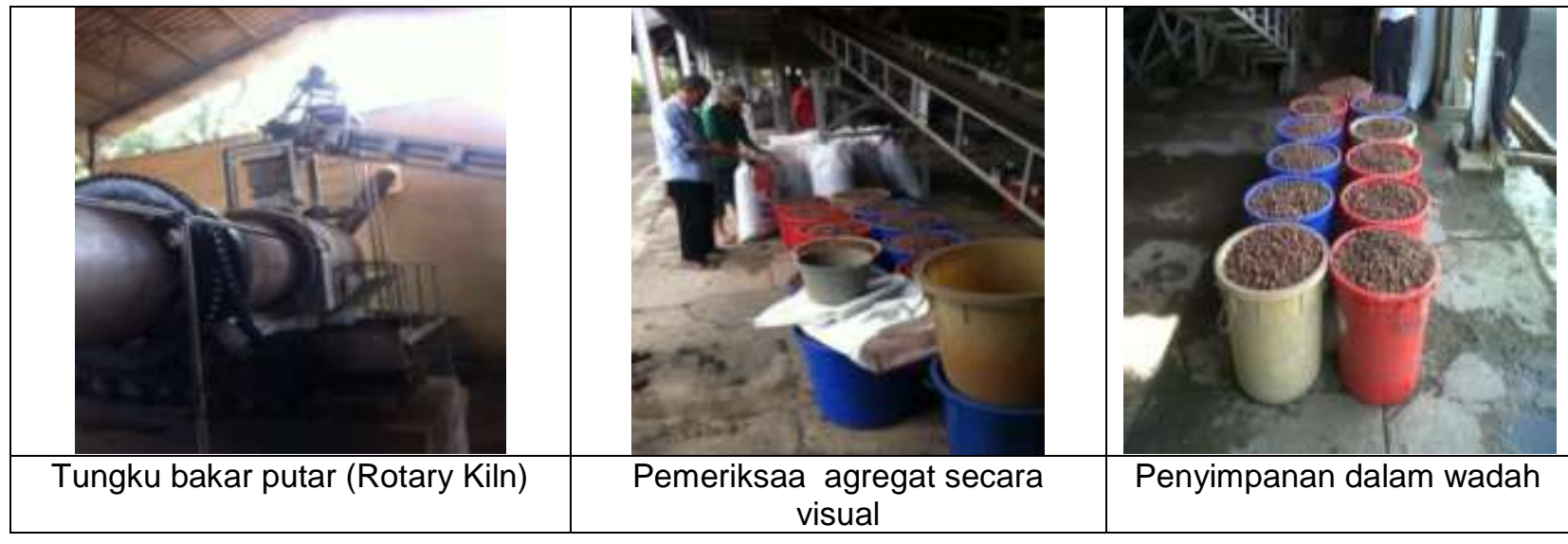

Gambar 2 Hasil pembakaran agregat ringan dengan tungku putar (rotarry kiln)

Hasil pengujian agregat ringan

Hasil pengujian agregat ringan hasil pembakaran lumpur Sidoarjo (Lusi) disajikan dalam Tabel 7 dan Tabel 8 berikut:

Tabel 7 Hasil pengujian agregat ringan (kasar/kerikil).

\begin{tabular}{|c|c|c|c|c|c|}
\hline \multirow[t]{2}{*}{ No } & \multirow[t]{2}{*}{ Uraian uji } & \multicolumn{3}{|c|}{$\begin{array}{c}\text { Hasil uji } \\
\text { Suhu bakar }\left({ }^{\circ} \mathrm{C}\right)\end{array}$} & \multirow{2}{*}{$\begin{array}{l}\text { Syarat mutu } \\
\text { (utk beton } \\
\text { struktural) }\end{array}$} \\
\hline & & $800^{\circ} \mathrm{C}$ & $900-1000^{\circ} \mathrm{C}$ & $1.100^{\circ} \mathrm{C}$ & \\
\hline 1 & Kadar air (\%) & 0,18 & 0,17 & 0,17 & \\
\hline 2 & Berat jenis $(\mathrm{g} / \mathrm{cc})$ & 1,45 & 1,31 & 1,23 & $1,0-1,8$ \\
\hline 3 & Penyerapan air (\%) & 18,35 & 18,63 & 26,49 & Maks. 20,0 \\
\hline \multirow[t]{3}{*}{4} & Bobot isi: & & & & \\
\hline & - gembur (kg/l) & 0,71 & 0,66 & 0,59 & - \\
\hline & - padat (kg/l) & 0,75 & 0,69 & 0,62 & - \\
\hline 5 & Nilai keremukan $10 \%$ (ton) & 8,2 & 9,6 & 7,8 & $9,0-14,0$ \\
\hline
\end{tabular}

Berdasarkan hasil pengujian agregat kasar (kerikil) pada tabel 4 diatas terlihat bahwa pada suhu bakar $800{ }^{\circ} \mathrm{C}$ mutu agregat belum cukup baik karena nilai kekerasannya hanya mencapai 8,2 sehingga belum memenuhi syarat. Pada suhu bakar antara

$900{ }^{\circ} \mathrm{C}-1.000{ }^{\circ} \mathrm{C}$ menghasilkan mutu agregat yang sangat baik dengan nilai kekerasan 9,6 $>9,0$, sedangkan pada suhu $1.100{ }^{\circ} \mathrm{C}$, nilai kekerasan kembali menurun, hal menandakan bahwa suhu bakar telah melewati titik sintering sehingga menjadi keropos dan $\operatorname{rapuh}^{[3]}$.

Tabel 8. Hasil pengujian agregat ringan (halus/pasir)

\begin{tabular}{|c|c|c|c|c|c|}
\hline \multirow[t]{2}{*}{ No } & \multirow[t]{2}{*}{ Uraian uji } & \multicolumn{3}{|c|}{$\begin{array}{c}\text { Hasil uji } \\
\text { Ukuran agregat nominal }(\mathrm{mm})\end{array}$} & \multirow{2}{*}{$\begin{array}{c}\text { Syarat mutu } \\
\text { (utk beton struktural) }\end{array}$} \\
\hline & & $2,38-4,76$ & $1,19-2,38$ & $0,15-1,19$ & \\
\hline 1 & Kadar air (\%) & 0,17 & 0,16 & 0,16 & \\
\hline 2 & Berat jenis $(\mathrm{g} / \mathrm{cc})$ & 1,45 & 1,53 & 1,58 & $1,0-1,8$ \\
\hline 3 & Penyerapan air (\%) & 18,93 & 19,04 & 21,46 & Maks. 20,0 \\
\hline \multirow[t]{3}{*}{4} & Bobot isi: & & & & \\
\hline & - gembur (kg/l) & 0,66 & 0,69 & 0,71 & - \\
\hline & - padat $(\mathrm{kg} / \mathrm{l})$ & 0,69 & 0,72 & 0,74 & - \\
\hline 5 & Nilai keremukan $10 \%$ (ton) & - & - & - & - \\
\hline
\end{tabular}


Sedangkan hasil pengujian agregat halus (pasir) pada tabel 5 diatas terlihat bahwa perbedaan ukuran agregat memberikan hasil yang berbeda, semakin halus ukuran agregat semakin besar berat jenis dan bobot isinya dikarenakan kandungan rongga didalamnya semakin kecil. Sedangkan hasil uji penyerapan air semakin besar karena jumlah butir dalam satuan volume semakin tinggi ${ }^{[1]}$.

\section{Hasil pengujian beton ringan}

Untuk mengetahu apakah agregat ringan yang dihasilkan tersebut dapat digunakan untuk pembuatan beton ringan struktural, maka dilakukan uji coba pembuatan beton dengan berbagai campuran yang tertuang dalam Tabel 9 dan hasil pengujian beton segar disajikan dalam Tabel 10 berikut ini:

Tabel 9 Proporsi campuran beton ringan

\begin{tabular}{ccccccccc}
\hline No & Kode & $\begin{array}{c}\text { Semen } \\
(\mathrm{kg})\end{array}$ & \multicolumn{2}{c}{ Agregat halus/pasir ringan $(\mathrm{kg})$} & $\begin{array}{c}\text { Kerikil ringan } \\
\text { 4,8-20 mm (kg) }\end{array}$ & Air (kg) & $\begin{array}{c}\text { Additive } \\
(\mathrm{L})\end{array}$ \\
\cline { 4 - 6 } & & $0-1,2 \mathrm{~mm}$ & $1,2-2,4 \mathrm{~mm}$ & $2,4-4,8 \mathrm{~mm}$ & & & \\
\hline 1 & Ao & 233 & 74,0 & 128,0 & 123,0 & 226,0 & 151,0 & - \\
2 & A & 233 & 74,0 & 128,0 & 123,0 & 226,0 & 151,0 & 14,0 \\
3 & B & 250 & 80,0 & 137,0 & 132,0 & 183,0 & 166,0 & 15,0 \\
4 & C & 285 & 91,0 & 148,0 & 150,0 & 140,0 & 186,0 & 17,0 \\
\hline
\end{tabular}

Tabel 10 Hasil pengujian beton segar

\begin{tabular}{cccccc}
\hline \multirow{2}{*}{ No } & Kode & \multicolumn{4}{c}{ Slump } \\
\cline { 2 - 5 } & & Berat jenis & Suhu $\left({ }^{\circ} \mathrm{C}\right)$ & Faktor pemadatan (\%) \\
\hline 1 & Campuran Ao & 22 & 1.238 & 27 & 95 \\
2 & Campuran A1 & 35 & 1.250 & 26 & 96 \\
3 & Campuran B & 50 & 1.287 & 26 & 97 \\
4 & Campuran C & 80 & 1.296 & 26 & 98
\end{tabular}

Dari hasil pengujian beton segar terlihat bahwa penambahan aditif dalam campuran beton memberikan pengaruh terhadap nilai slump, tingkat kepadatandan suhu beton yang dihasilkan ${ }^{[10]}$. Semakin tinggi kadar additive menghasilkan nilai slump dan factor pemadatan semakin besar sedangkan suhu beton menjadi semakin rendah. Sedangkan berat jenis semakin tinggi, hal ini disebabkan oleh kandungan air yang semakintinggi dimana serta fungsi additive sebagai bahan untuk meningkatkan kelecakan beton yang juga berdampak terhadap kemudahan pengerjaan dan pemadatannya ${ }^{[17]}$.

\section{Hasil pengujian kuat tekan}

Hasil pengujian kuat tekan disajikan dalam Tabel 11, Tabel 12, Tabel 13, dan Tabel 14

berikut:

Tabel 11 Hasil pengujian kuat tekan campuran Ao.

\begin{tabular}{cccccccccc}
\hline \multirow{2}{*}{ No } & \multirow{2}{*}{ Kode } & $\begin{array}{c}\text { Umur } \\
\text { (hari) }\end{array}$ & \multicolumn{2}{c}{ Ukuran $(\mathrm{cm})$} & \multicolumn{1}{c}{ Luas bid } & Bekan $\left(\mathrm{cm}^{2}\right)$ & $\begin{array}{c}\text { Berat } \\
(\mathrm{gr})\end{array}$ & $\begin{array}{c}\text { Beban } \\
(\mathrm{kg})\end{array}$ & \multicolumn{2}{c}{ Kuat tekan $\left(\mathrm{kg} / \mathrm{cm}^{2}\right)$} \\
Masing $^{2}$ & Rata-rata \\
\hline 1 & Camp. & & 20,0 & 10,0 & 78,5 & 2.037 & 8.210 & 104,62 & \\
2 & Ao & \multirow{3}{*}{3} & 20,0 & 10,0 & 78,5 & 2.018 & 7.870 & 100,24 & 102,50 \\
3 & & & 20,0 & 10,0 & 78,5 & 2.030 & 8.060 & 102,64 & \\
1 & Camp. & & 20,0 & 10,0 & 78,5 & 2.015 & 10.940 & 139,32 & \\
2 & Ao & 7 & 20,0 & 10,0 & 78,5 & 2.022 & 11.150 & 142,12 & 139,60 \\
3 & & & 20,0 & 10,0 & 78,5 & 2.012 & 10.780 & 137,36 & \\
1 & Camp. & & 20,0 & 10,0 & 78,5 & 2.027 & 14.100 & 179,62 & \\
2 & Ao & 28 & 20,0 & 10,0 & 78,5 & 1.966 & 14.300 & 182,17 & 181,34 \\
3 & & & 20,0 & 10,0 & 78,5 & 1.953 & 14.000 & 178,34 & \\
\hline
\end{tabular}


Tabel 12 Hasil pengujian kuat tekan campuran A1.

\begin{tabular}{cccccccccc}
\hline \multirow{2}{*}{ No } & Kode & $\begin{array}{c}\text { Umur } \\
\text { (hari) }\end{array}$ & $\begin{array}{c}\text { Ukuran }(\mathrm{cm}) \\
\mathrm{H}\end{array}$ & $\begin{array}{c}\text { Luas bid } \\
\text { tekan }\left(\mathrm{cm}^{2}\right)\end{array}$ & $\begin{array}{c}\text { Berat } \\
(\mathrm{gr})\end{array}$ & $\begin{array}{c}\text { Beban } \\
(\mathrm{kg})\end{array}$ & \multicolumn{2}{c}{ Kuat tekan $\left(\mathrm{kg} / \mathrm{cm}^{2}\right)$} \\
Masing $^{2}$ & Rata-rata \\
\hline 1 & Camp. & & 20,0 & 10,0 & 78,5 & 1.882 & 8.580 & 109,30 & \\
2 & $\mathrm{~A}_{1}$ & \multirow{3}{*}{3} & 20,0 & 10,0 & 78,5 & 1.885 & 8.600 & 109,60 & 109,07 \\
3 & & & 20,0 & 10,0 & 78,5 & 1.918 & 8.500 & 108,30 & \\
\hline 1 & Camp. & & 20,0 & 10,0 & 78,5 & 1.813 & 11.200 & 142,58 & \\
2 & $\mathrm{~A}_{1}$ & 7 & 20,0 & 10,0 & 78,5 & 1.889 & 11.700 & 149,04 & 145,19 \\
3 & & & 20,0 & 10,0 & 78,5 & 1.882 & 11.300 & 143,95 & \\
\hline 1 & Camp. & & 20,0 & 10,0 & 78,5 & 2.027 & 14.400 & 183,44 & \\
2 & $\mathrm{~A}_{1}$ & 28 & 20,0 & 10,0 & 78,5 & 1.967 & 14.300 & 182,20 & 183,88 \\
3 & & & 20,0 & 10,0 & 78,5 & 1.953 & 14.600 & 186,00 & \\
\hline
\end{tabular}

Tabel 13 Hasil pengujian kuat tekan campuran B.

\begin{tabular}{|c|c|c|c|c|c|c|c|c|c|}
\hline \multirow[b]{2}{*}{ No } & \multirow[b]{2}{*}{ Kode } & \multirow{2}{*}{$\begin{array}{l}\text { Umur } \\
\text { (hari) }\end{array}$} & \multicolumn{2}{|c|}{ Ukuran $(\mathrm{cm})$} & \multirow{2}{*}{$\begin{array}{l}\text { Luas bid } \\
\text { tekan }\left(\mathrm{cm}^{2}\right)\end{array}$} & \multirow{2}{*}{$\begin{array}{c}\text { Berat } \\
\text { (gr) }\end{array}$} & \multirow{2}{*}{$\begin{array}{l}\text { Beban } \\
(\mathrm{kg})\end{array}$} & \multicolumn{2}{|c|}{ Kuat tekan $\left(\mathrm{kg} / \mathrm{cm}^{2}\right)$} \\
\hline & & & $\mathrm{H}$ & D & & & & Masing $^{2}$ & Rata-rata \\
\hline 1 & Camp. & & 20,0 & 10,0 & 78,5 & 2.109 & 10.700 & 136,30 & \\
\hline 2 & B & 3 & 20,0 & 10,0 & 78,5 & 2.090 & 9.880 & 125,86 & 128,58 \\
\hline 3 & & & 20,0 & 10,0 & 78,5 & 2.010 & 9.700 & 123,57 & \\
\hline 1 & Camp. & & 20,0 & 10,0 & 78,5 & 1.990 & 12.200 & 155,41 & \\
\hline 2 & B & 7 & 20,0 & 10,0 & 78,5 & 2.011 & 12.000 & 152,87 & 154,14 \\
\hline 3 & & & 20,0 & 10,0 & 78,5 & 2.014 & 12.100 & 154,14 & \\
\hline 1 & Camp. & & 20,0 & 10,0 & 78,5 & 2.017 & 15.500 & 197,50 & \\
\hline 2 & B & 28 & 20,0 & 10,0 & 78,5 & 2.027 & 16.000 & 203,80 & 201,70 \\
\hline 3 & & & 20,0 & 10,0 & 78,5 & 2.022 & 16.000 & 203,80 & \\
\hline
\end{tabular}

Tabel 14 Hasil pengujian kuat tekan campuran $\mathrm{C}$.

\begin{tabular}{|c|c|c|c|c|c|c|c|c|c|}
\hline \multirow{2}{*}{ No } & \multirow{2}{*}{ Kode } & \multirow{2}{*}{$\begin{array}{l}\text { Umur } \\
\text { (hari) }\end{array}$} & \multicolumn{2}{|c|}{ Ukuran $(\mathrm{cm})$} & \multirow{2}{*}{$\begin{array}{l}\text { Luas bid } \\
\text { tekan }\left(\mathrm{cm}^{2}\right)\end{array}$} & \multirow{2}{*}{$\begin{array}{l}\text { Berat } \\
\text { (gr) }\end{array}$} & \multirow{2}{*}{$\begin{array}{l}\text { Beban } \\
(\mathrm{kg})\end{array}$} & \multicolumn{2}{|c|}{ Kuat tekan $\left(\mathrm{kg} / \mathrm{cm}^{2}\right)$} \\
\hline & & & $\mathrm{H}$ & D & & & & Masing $^{2}$ & Rata-rata \\
\hline 1 & Camp. & & 20,0 & 10,0 & 78,5 & 2.180 & 10.880 & 137,58 & \\
\hline 2 & C & 3 & 20,0 & 10,0 & 78,5 & 2.162 & 11.400 & 145,22 & 141,40 \\
\hline 3 & & & 20,0 & 10,0 & 78,5 & 2.154 & 11.100 & 141,40 & \\
\hline 1 & Camp. & & 20,0 & 10,0 & 78,5 & 2.148 & 12.500 & 159,23 & \\
\hline 2 & C & 7 & 20,0 & 10,0 & 78,5 & 2.094 & 12.300 & 156,69 & 157,14 \\
\hline 3 & & & 20,0 & 10,0 & 78,5 & 2.094 & 12.100 & 154,14 & \\
\hline 1 & Camp. & & 20,0 & 10,0 & 78,5 & 2.089 & 16.000 & 203,8 & \\
\hline 2 & C & 28 & 20,0 & 10,0 & 78,5 & 2.119 & 16.200 & 206,4 & 204,70 \\
\hline 3 & & & 20,0 & 10,0 & 78,5 & 2.078 & 16.000 & 203,8 & \\
\hline
\end{tabular}

Berdasarkan hasil uji kuat tekan dari ke 4 proporsi campuran diatas terlihat bahwa seluruh campuran dapat mencapai kekuatan diatas 17 $\mathrm{MPa}$ dan memenuhi syarat minimum untuk beton struktural ${ }^{[11]}$, sesuai yang disyaratkan dalam SNI 2847:2013 Persyaratan beton struktural untuk bangunan gedung. Sedangkan kekuatannya semakin menngkat dikarenakan kandungan semen yang semakin tinggi serta pengaruh penggunaan bahan additive selain dapat memperbaiki sifat beton segar juga dapat meningkatkan kekuatannya karena beton menjadi semakin padat dan kompak ${ }^{[12]}$.

\section{Hasil pengujian kuat tarik}

Pengujian kuat tarik beton ringan dengan agregat ringan lusi menggunakan benda uji berbentuk silinder ukuran tinggi $30 \mathrm{~cm}$ dan diameter $15 \mathrm{~cm}$ dimaksudkan untuk mengetahui kuat tarik yang dihasilkan dari berbagai campuran. Hasil pengujian dari berbagai variasi campuran disajikan dalam Tabel 15 berikut: 
Tabel 15 Hasil pengujian kuat tarik beton ringan campuran A1, B dan C.

\begin{tabular}{cccccccccc}
\hline No & \multirow{2}{*}{ Kode } & $\begin{array}{c}\text { Umur } \\
\text { (hari) }\end{array}$ & $\begin{array}{c}\text { Ukuran }(\mathrm{cm}) \\
\mathrm{H}\end{array}$ & $\begin{array}{c}\text { Luas bid } \\
\text { tarik }\left(\mathrm{cm}^{2}\right)\end{array}$ & $\begin{array}{c}\text { Berat } \\
(\mathrm{gr})\end{array}$ & $\begin{array}{c}\text { Beban } \\
(\mathrm{kg})\end{array}$ & \multicolumn{2}{c}{ Kuat tarik $\left(\mathrm{kg} / \mathrm{cm}^{2}\right)$} \\
Masing $^{2}$ & Rata-rata \\
\hline 1 & Camp. & & 30,0 & 15,0 & 1.413 & 6.810 & 13.920 & 19,7 & \\
2 & $\mathrm{~A}_{1}$ & 28 & 30,0 & 15,0 & 1.413 & 6.982 & 15.050 & 21,3 & 20,4 \\
3 & & & 30,0 & 15,0 & 1.413 & 6.996 & 14.200 & 20,1 & \\
\hline 1 & Camp. & & 30,0 & 15,0 & 1.413 & 6.982 & 15.440 & 26,1 & \\
2 & $\mathrm{~B}$ & \multirow{2}{*}{28} & 30,0 & 15,0 & 1.413 & 6.978 & 18.020 & 25,5 & 25,6 \\
3 & & & 30,0 & 15,0 & 1.413 & 6.972 & 17.800 & 25,2 & \\
\hline 1 & Camp. & & 30,0 & 15,0 & 1.413 & 6.898 & 22.115 & 31,3 & \\
2 & $\mathrm{C}$ & \multirow{2}{2}{28} & 30,0 & 15,0 & 1.413 & 6.874 & 22.960 & 32,5 & 32,4 \\
3 & & & 30,0 & 15,0 & 1.413 & 6.826 & 23.600 & 33,4 & \\
\hline
\end{tabular}

Berdasarkan hasil uji kuat tarik dari ke 3 proporsi campuran diatas terlihat bahwa seluruh campuran dapat mencapai kekuatan diatas 2,0 $\mathrm{MPa}$ dan memenuhi syarat minimum untuk beton struktural ${ }^{[6]}$, sesuai yang disyaratkan dalam SNI 2847:2013 Persyaratan beton struktural untuk bangunan gedung. Sedangkan pengaruh penambahan semen dan penggunaan bahan additive dapat meningkatkan kekuatan tarik secara significan, karena beton menjadi semakin lekat ${ }^{[13]}$.

\section{Hasil pengujian kuat lentur beton ringan}

Tabel 16 Hasil pengujian kuat lentur beton ringan campuran $A, B$ dan $C$.

\begin{tabular}{|c|c|c|c|c|c|c|c|c|c|c|}
\hline \multirow{2}{*}{ No } & \multirow{2}{*}{$\begin{array}{l}\text { Kode } \\
\text { Bahan }\end{array}$} & \multirow{2}{*}{$\begin{array}{l}\text { Umur } \\
\text { (hari) }\end{array}$} & \multicolumn{3}{|c|}{ Ukuran $(\mathrm{cm})$} & \multirow{2}{*}{$\begin{array}{l}\text { Berat } \\
\text { (gr) }\end{array}$} & \multirow{2}{*}{$\begin{array}{c}\text { Beban } \\
(\mathrm{kg})\end{array}$} & \multirow[b]{2}{*}{$\mathrm{L}_{1}$} & \multicolumn{2}{|c|}{ Kuat lentur $\left(\mathrm{kg} / \mathrm{cm}^{2}\right)$} \\
\hline & & & $\mathrm{L}_{0}$ & $b$ & $\mathrm{~h}$ & & & & Masing $^{2}$ & Rata-rata \\
\hline 1 & & & 40,0 & 10,0 & 10,0 & 4.885 & 600 & 30,0 & 27,0 & \\
\hline 2 & Camp. & 28 & 40,0 & 10,0 & 10,0 & 4.757 & 650 & 30,0 & 29,0 & 28,5 \\
\hline 3 & $A_{1}$ & & 40,0 & 10,0 & 10,0 & 4.759 & 650 & 30,0 & 29,0 & \\
\hline 1 & & & 40,0 & 10,0 & 10,0 & 5.215 & 720 & 30,0 & 32,4 & \\
\hline 2 & Camp. & 28 & 40,0 & 10,0 & 10,0 & 5.252 & 740 & 30,0 & 33,3 & 33,2 \\
\hline 3 & B & & 40,0 & 10,0 & 10,0 & 5.234 & 750 & 30.0 & 33,8 & \\
\hline 1 & & & 40,0 & 10,0 & 10,0 & 5.338 & 750 & 30,0 & 33,8 & \\
\hline 2 & Camp. & 28 & 40,0 & 10,0 & 10,0 & 5.396 & 760 & 30,0 & 34,2 & 33,8 \\
\hline 3 & C & & 40,0 & 10,0 & 10,0 & 5.387 & 740 & 30,0 & 33,3 & \\
\hline
\end{tabular}


Berdasarkan hasil uji kuat tarik dari ke 3 proporsi campuran diatas terlihat bahwa seluruh campuran dapat mencapai kekuatan diatas 2,0 MPa dan memenuhi syarat minimum untuk beton struktural ${ }^{[6]}$, sesuai yang disyaratkan dalam SNI 2847:2013 Persyaratan beton struktural untuk bangunan gedung. Sedangkan pengaruh penggunaan bahan additive dapat meningkatkan kekuatan lentur secara significan, karena beton menjadi semakin lekat dan plastis ${ }^{[14]}$.

\section{KESIMPULAN}

a. Saat ini semburan lumpur masih berlangsung dengan kapasitas sebesar $30.000 \mathrm{~m}^{3}$ sampai dengan $80.000 \mathrm{~m}^{3}$ per hari dengan suhu di pusat semburan > $100^{\circ} \mathrm{C}$, hal ini disebabkan masih tingginya tekanan dari dalam bumi sehingga masih memerlukan penanganan dan pengendalian yang lebih baik;

b. Kandungan kimia dalam lumpur didominasi oleh silika, alumina dan besi dengan jumlah dari ketiga unsur tersebut lebih dari $87 \%$.Kondisi ini mengindikasikan bahwa secara mendasar bahan tersebut cukup baik untuk digunakan sebagai bahan baku keramik, seperti agregat ringan buatan (artificial light weight aggregate);

c. Untuk pembuatan agregat ringan diperlukan pembakaran dengan suhu antara $900^{\circ} \mathrm{C}$ sampai dengan $1.000^{\circ} \mathrm{C}$, karena pada suhu dibawah $900^{\circ} \mathrm{C}$ agregat belum cukup matang dan pada suhu $1.100^{\circ} \mathrm{C}$ agregat menjadi gosong dan meleleh/menggumpal menjadi satu karena telah melampaui suhu sinterring;

d. Agregat ringan memiliki sifat teknis yang sangat baik, dengan densitas 0,6 - 0,7 $\mathrm{kg} / \mathrm{L}$ dannilai kekerasan 9,6 ton, sehingga memenuhi syarat SNI 2461:2014 persyaratan agregat ringan untuk beton ringan struktural;

e. Beton ringan yang dihasilkan memiliki karakteristik yang cukup baik dan memenuhi syarat SNI 2847:2013 persyaratan beton struktural untuk bangunan gedung dengan kuat tekan > $17,0 \mathrm{MPa}$, kuat tarik > 2,0 $\mathrm{MPa}$ dan densitas antara $1.300-1.400 \mathrm{~kg} / \mathrm{m}^{3}$.

\section{UCAPAN TERIMAKASIH}

Pada kesempatan ini kami ucapkan terima kasih kepada rekan-rekan peneliti dan teknisi di Laboratorium Bahan dan Struktur Bangunan, Puslitbang Perumahan dan Permukiman, yang telah membantu dalam penelitian ini. Ucapan terima kasih juga kami sampaikan kepada yang terhormat Kepala Pusat Penelitian dan Pengembangan Perumahan dan Permukiman serta Kepala Balai Litbang Bahan dan Struktur Bangunan yang telah memberi kesempatan dan dukungannya kepada penulis untuk melaksanakan penelitian ini.

\section{DAFTAR PUSTAKA}

.......2014, SNI 2461:2014, Spesifikasi Agregat Ringan untuk Beton Struktur, Jakarta, BSN;

Sugiarto, A. dan Lasino. 2014; Pengembangan agregat dari tanah (ARTA) di Merauke- Papua.Informasi teknologi keramik dan gelas. Volum 35. No.1. Balai Besar Keramik. Bandung;

.2014, Artificial Lightweight Aggregate dari Lempung Bekah, Pusat Litbang Perumahan dan Permukiman, Badan Litbang Pekerjaan Umum dan Perumahan Rakyat, Bandung;

Indonesia.2012;Tata cara pemilihan campuran untuk beton normal, beton berat dan beton massa. SNI No. 7656-2012. Jakarta: BSN;

Sugiharto, B. 2014; Pengembangan panel ringan dengan agregat ringan buatan (artificioal lightweight aggregate). Laporan Penelitian, Pusat Litbang Perumahan dan Permukiman, Badan Litbang Pekerjaan Umum dan Perumahan Rakyat, Bandung;

Suripto MA. 1995; Teknologi Bahan Bangunan dari Tanah Liat, Balai Besar Industri Keramik, Bandung;

Randing, 1996; Penelitian Tanah Liat dari Lahan Gambut Kalimantan Tengah untuk Bahan Bangunan, Jurnal Penelitian Permukiman, Vol.XII No. 7-8/9-10, halaman 1 - 13, Bandung;

Michael Segetin, Krishnan Jayaraman, Xun Xu. 2007; "Harakeke reinforcement of soil-cement building materials: Manufacturability and properties", Building and Environment 42 (2007) 3066-3079;

Sugiharto, B. 2009; Pengembangan Bahan Bangunan Alternatif Dari Lumpur Lapindo Dengan Bahan Aditif, Laporan akhir, Puslitbang Permukiman, Bandung;

Pujianto, As'at dkk. 2013;Beton mutu tinggi dengan admixture superplastiziser dan additive silica fume. Yogyakarta: Universitas Muhammadiyah Yogyakarta; 
2013, SNI 2847:2013, Persyaratan Beton Struktural untuk Bangunan Gedung, Jakarta, BSN;

Yoshihiko Ohama. (1995). Handbook of Polymer-Modified Concrete And Mortars : Properties and Process Technology, Noyes Publications, New Jersey, USA;

Nakwoon Choi, Seongjin Yoon, Kyoungju Mun, dan Yangseob Soh. 2004; Polyester Mortars With Fine Tailing As Filler, Proceedings of RILEM International Symposium on Environment-Conscious Materials and Systems for Sustainable Development page 425-432, ISBN 2912143640;

Jin Liu, Bin Shi, Hongtao Jiang, Sunyoung Bae, He Huang. 2009; "Improvement of water-stability of clay aggregates admixed with aqueous polymer soil stabilizers", Catena 77, 175-179;

American Concrete Institute. 1997; Guide for the Use of Polymers in Concrete, ACI 548.1R97 ;

Lioyd, N.A dan Rangan, B. V. 2010; Geopolymer Concrete with Fly Ash, Curtin University of Technology, Western Australia;

Marinela Bărbuţă \& Maria Harja. 2008; Experimental Study On The Characteristics Of Polymer Concrete With Epoxy Resin, Buletinul Institutului Politehnic;

Peraturan Menteri Pekerjaan Umum dan Perumahan Rakyat No. 2 Tahun 2015 tanggal 18 Pebruari 2015, Tentang Bangunan Gedung Hijau;

Adiwoso, N: 2015; Kriteria Penilaian Konstruksi Hijau, Green Building Council Indonesia (GBCl), Jakarta;

Prastowo, B: 2015; Pengembangan Sistem Konstruksi Hijau, Direktoratjenderal Cipta Karya, Jakarta;

Subyakto: 2015; Penerapan Green Label dalam mendukung Pembangunan Berkelanjutan, Lembaga IImu Pengetahuan Indonesia (LIPI), Jakarta;

Murni, A: 2015; Green Product for Green Building, Green Product Council Indonesia (GPCl), Jakarta;

Nurmayanti, S: 2015; Kebijakan Pengembangan dan Penerapan Ekolabel Indonesia, Kementerian Lingkungan Hidup dan Kehutanan, Jakarta;
Kementerian Lingkungan Hidup dan Kehutanan: 2013: Kajian Teknis Kriteria Ekolabel, Jakarta.

Tavio dan Lasino. 2015; Tata Cara Penentuan Proposi Campuran Beton dengan Menggunakan Semen Portland Biasa, Semen Portland Pozzolan dan Semen Portland Komposit, CV. Cipta Dea Pustaka, Bandung ;

M. Ghrici, S. Kenai, M. Said-Mansour, 2007, Mechanical properties and durability of mortar and concrete containing natural pozzolana and limestone blended cements, Cement and concrete composite research volume 29 , issue 7 , August 2007, page 542-549;

J.S. Pasaribu, Rahmi. K, 2014, Analisis Penggunaan Berbagai Merk Semen Portland Type I Untuk Pembuatan Beton f'c $20 \mathrm{MPa}$ Dengan Menggunakan Agregat Dari Binjai, Jurnal Teknik Sipil USU, Vol. 3 No. 1. Universitas Sumatera Utara Medan;

Kusumastuti.E, 2012. Pemanfaatan Abu Vulkanik Gunung Merapi Sebagai Geopolimer (Suatu Polimer Anorganik Aluminosilikat), Jurnal MIPA, Universitas Negeri Semarang.;

Susanti, Eka. 2012. Studi Perbandingan Nilai Kuat Tekan dan Modulus Elastisitas Beton yang Menggunakan Pasir Merapi dan Pasir Lumajang, Prosiding Seminar Nasional Aplikasi Teknologi Prasarana Wilayah 18 Juni 2014. Surabaya. 